\title{
Cogeneration in electrical microgrids
}

\author{
I. Zamora ', J.I. San Martín ${ }^{2}$, A.J. Mazon ', J.J. San Martín², V. Aperribay ${ }^{2}$, J.M $^{a}$. Arrieta ${ }^{2}$ \\ Department of Electrical Engineering - University of the Basque Country \\ ${ }^{1}$ Escuela Técnica Superior de Ingeniería de Bilbao \\ Alda. Urquijo, 48013 Bilbao (Spain) - e_mail: inmaculada.zamora@ehu.es \\ ${ }^{2}$ Escuela Universitaria de Ingeniería Técnica Industrial de Eibar \\ Avda. Otaola, 29, 20600 Eibar (Spain) - e_mail: iepsadij@sb.ehu.es
}

\begin{abstract}
Simultaneous generation of electrical and useful thermal energy (hot, cold, or both) is an obvious way to optimize the consumed energy efficiency. In the last decade, cogeneration has had, in a world level, a big deployment, thanks to the use of gas and the fact of taking advantage of biomass and other waste products energetically valuable. However, there are possibilities to extend cogeneration applications by means of new technologies of multiple generation of: electrical power, heat, cold, desalination and/or regeneration of water and chemical products in general.
\end{abstract}

The priority performances about this context are being centered in the development and researching of a distinguished group of electrical micro-generation technologies, which energetic benefits highlight because of a high global index of efficiency. In this group of advanced technologies Fuel Cells, Stirling Motor and Gas Microturbines are included.

\section{Key words}

Cogeneration, Fuel Cells, Stirling Motor, Gas Microturbines.

\section{Introduction}

This paper presents the current state of development about more highlight technologies, in the field of distributed generation, which are involved in cogeneration and poligeneration processes.

The European Directive [1] considers as high efficiency cogeneration, the one that allows saving energy by means of combined production, instead of a separate one, in a quantity higher than $10 \%$. In this directive, several technologies are contemplated, being highlighted those that are used in the field of electrical micro-grids. [2]

In this sense, we should remember that electrical power is the more appropriate way of energy for a lot of applications, not only in the industry but also in the residential and tertiary sectors. It is a superior quality energy, which means that its energy content is $100 \%$ [3]. Because of that, it can become heat, mechanical power or whatever way of energy. Nevertheless, in the electrical production processes by traditional means, some energy contained in the fuel is loosed. This aspect can be analysed in the modern gas turbines, which electrical efficiency is approximately $42 \%$ and in the ones that work in a combined cycle, with an efficiency up to $55 \%$. In this scenario, these technologies would reach a total efficiency up to $87 \%$ and $90 \%$, respectively.

\section{General aspects about cogeneration and trigeneration}

In cogeneration systems, the fuel quantity used to generate electrical and thermal energy is much lower than the one used in conventional systems of electrical and thermal generation separately. In other words, in a conventional thermoelectrical central, from $100 \%$ of energy contained in fuel about $33 \%$ become electrical power. The rest is loosed through the capacitor, the exhaust gases, mechanical looses, electrical looses by transmission and distribution and others.

In cogeneration systems, values near to $84 \%$ of energy contained in the fuel are used for the electrical power and heat generation for processes (25-30\% electrical and 59$54 \%$ thermal). These quantities can be seen in figures 1(a) and 1(b).

In this context, trigeneration is defined as the simultaneous production of electrical power, heat energy and cold energy. A trigeneration system is got when assembling a cogeneration system (CHP) with and absorption machine, to produce cold. In order to calculate the REE it is considered that cold obtained has been made in an absorption machine that uses heat produced in the cogeneration plant. 


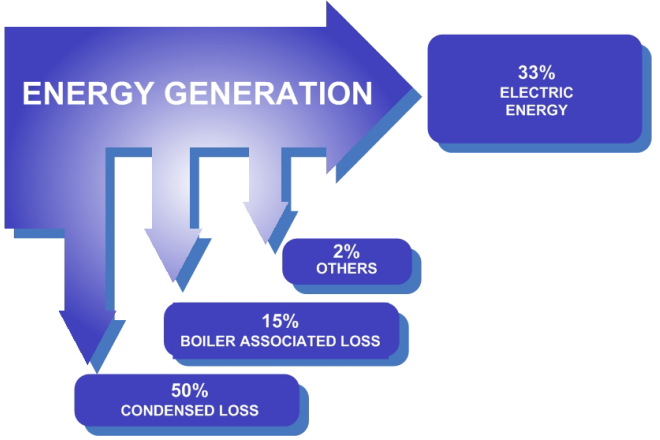

Fig 1(a). Conventional electrical power generation

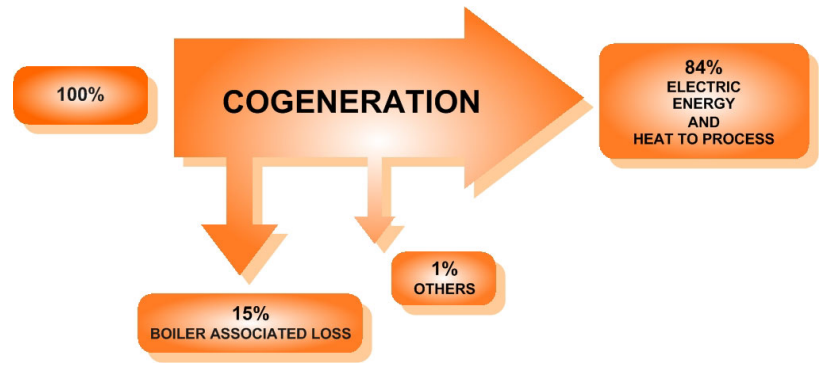

Fig. 1(b). Total energy generation with cogeneration

Trigeneration usually is used in air conditioning systems for industrial processes, buildings, hothouses, etc. The Contemporary Art Centre "Baltic" placed in Gateshead ("United Kingdom") presents a trigeneration system that is highly flexible and efficient. It is designed to be automatically isolated from the main grid when there are problems and to keep on supplying electrical power to the essential electrical and emergency loads of the building. When the steady state supply from de grid comes back, the system is synchronized again, automatically, to work in parallel with the main grid.

By other side, fourth type of generation is known as the process that saves energy (associated with the three mentioned before) and allows capturing $\mathrm{CO}_{2}$ of the exhaust gases. This $\mathrm{CO}_{2}$ can be used to elaborate drinks or in hothouses. This last version allows improvements in a double way: increasing the efficiency and reducing polluted emissions in microgeneration technologies. In this sense, $\mathrm{CO}_{2}$ dissolved in beer, increases the acidity and eliminates oxygen, allowing conserving better the natural or added components. In the hothouses, the increasing of $\mathrm{CO}_{2}$ make easier the chlorophyllian function of plants, and the production increasing can reach $20 \%$.

The more relevant features associated with the traditional and emergent technologies that contemplate cogeneration processes are presented in table 1 .

In order to select the most appropriate technology several criteria exist, such as: electrical power produced by the device, relation between the electrical and thermal demand, pressure of the produced vapour, etc.
TABLE 1. - Cogeneration Technology Characteristics. Source: UNEP

\begin{tabular}{|c|c|c|c|c|}
\hline TECHNOLOGY & FUEL & SIZE (MW.) & $\begin{array}{c}\text { ELECTRICAL } \\
\text { EFFICIENCY }\end{array}$ & $\begin{array}{c}\text { OVERALL } \\
\text { EFFICIENCY }\end{array}$ \\
\hline \hline Steam Turbine & Any & $0,5-500$ & $7-20 \%$ & $60-80 \%$ \\
\hline Gas Turbine & $\begin{array}{c}\text { Gaseous and } \\
\text { liquid fuels }\end{array}$ & $\mathbf{0 , 2 5 - 5 0 +}$ & $25-42 \%$ & $65-87 \%$ \\
\hline Combined cycle & $\begin{array}{c}\text { Gaseous and } \\
\text { liquid fuels }\end{array}$ & $\mathbf{3 - 4 0 0 +}$ & $\mathbf{3 5 - 5 5 \%}$ & $\mathbf{7 3 - 9 0 \%}$ \\
\hline $\begin{array}{c}\text { Diesel and Otto } \\
\text { engines }\end{array}$ & $\begin{array}{c}\text { Gaseous and } \\
\text { liquid fuels }\end{array}$ & $\mathbf{0 , 0 0 3 - 2 0}$ & $\mathbf{2 5 - 4 5 \%}$ & $\mathbf{6 5 - 9 2 \%}$ \\
\hline $\begin{array}{c}\text { Microturbines } \\
\text { Gaseous and } \\
\text { liquid fuels }\end{array}$ & $\mathbf{0 , 0 2 5 - 0 , 3 +}$ & $15-30 \%$ & $60-85 \%$ \\
\hline Fuel cells & $\begin{array}{c}\text { Gaseous and } \\
\text { liquid fuels }\end{array}$ & $\mathbf{0 , 0 0 3 - 3 +}$ & App $37-50 \%$ & $\mathbf{A p p} 85-90 \%$ \\
\hline Stirling engines & $\begin{array}{c}\text { Gaseous and } \\
\text { liquid fuels }\end{array}$ & $\mathbf{0 , 0 0 3 - 1 , 5}$ & App $40 \%$ & $65-85 \%$ \\
\hline
\end{tabular}

Figure 2 shows the electrical generation efficiency of different technologies, considering the low heat value of the fuel and the more appropriate power ranges.

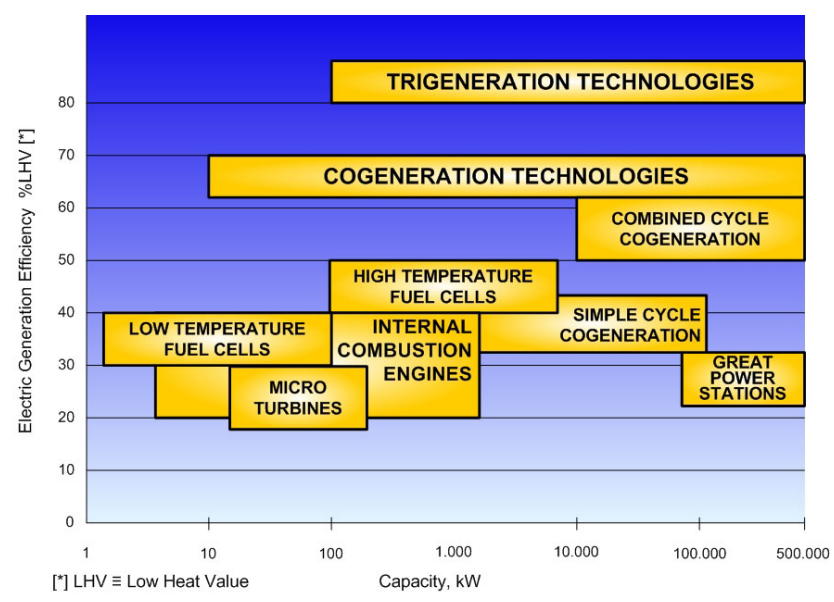

Fig 2. Efficiency and power ranges of several technologies

\section{Fuel Cells}

A fuel cell is an electrochemical device capable of converting chemical energy of the reagents (a fuel and an oxidant) directly into electrical power of low voltage. This transformation is got by means of an electrochemical reaction, in which, the oxidant usually is air or oxygen.

By other side, since the product that is oxidized is not part of the fuel cell structure and both products can be supplied uninterruptedly, the electrical power production will persist while there are reagents.

Comparing fuel cells with rechargeable batteries, in the later the chemical energy of the electrodes becomes electricity and, when it is over, it needs a recharge process that regenerates the chemical energy from electricity. However, in fuel cells the chemical energy comes from a fuel that is supplied from the outside. Its operation method is the contrary to the electrolysis. For instance, in the water electrolysis it is separated in hydrogen and oxygen, meanwhile in fuel cells we will obtain electrical current, water and heat. 


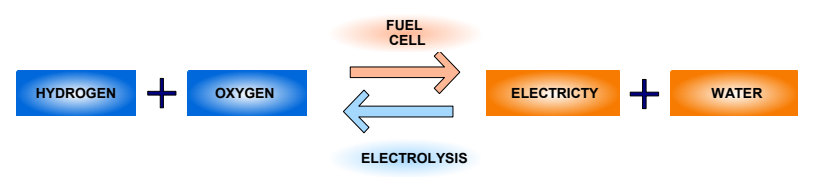

Fig 3. Scheme of the transformation process

The type of fuel used goes from hydrogen until simple hydrocarbons and derived, such as alcohols. The use of pure fuels eliminates problems related with pollution, like $\mathrm{S}, \mathrm{NO}, \mathrm{V}$, etc. By other side, hydrogen does not generate, derives such as $\mathrm{CO}$ and $\mathrm{CO}_{2}$. Hydrocarbon does it, but because of the high efficiency of fuel cells, for equivalent quantities of produced energy, the $\mathrm{CO}_{2}$ emissions can be reduced to the middle or less, with an important environmental benefit.

The electrochemical conversion of the chemical energy in useful work has an intrinsic efficiency much higher than the one of the thermal machines. These thermal machines have efficiency limitations already recognized by its author, Carnot, since the same moment of creation. Thus, in his work "Reflexions sur la puissance motrice du feu" indicates that the maximum efficiency of thermal systems vary from 40 to $45 \%$.

Since a fuel cell converts directly chemical energy of the "fuel" in work, without needing a Carnot cycle, its efficiency is not limited to this cycle, and theoretically it could arrive to $100 \%$. However, in practice, overvoltages determine maximum electrical efficiencies around 50-60 $\%$. But, it must be kept in mind that the mentioned electrochemical reactions are exothermic, so the use of heat and electricity (cogeneration) produce a higher global efficiency, approximately up to $85 \%$. [4]

$$
\eta_{\text {Total }}=\frac{Q+E}{Q_{o}}
$$

where $\mathrm{Q}$ is the thermal energy obtained, $\mathrm{E}$ is the electrical power produced in the fuel cell and $Q_{o}$, is the energy available in the fuel. This option is very used in applications of fuel cells in medium or high power stations.

In fuel cells, the maximum quantity of thermal energy that can be produced isothermicly and isostaticly, by means of a global reaction, is the enthalpy variation, $\Delta H$. But the fuel cell only can convert in electrical power an equivalent fraction to the free energy of Gibbs, $\Delta G$, being $\Delta H=\Delta G+T \cdot \Delta S$. The difference $T \cdot \Delta S$ is the minimum fraction of heat that is produced in an isothermic and isostatic process.

In this context, fuel cells type SOFC can form hybrid groups with gas micro-turbines, because the flow of exhaust gases of this fuel cell has very high temperature. Therefore, by means of a regenerator, it can heat the air from the compressor that later will activate the microturbine to obtain electrical power. This technique allows obtaining global efficiencies higher than $85 \%$.
Molten carbonate fuel cell (MCFC) can be used in trigeneration systems. In these fuel cells the exhaust gases emitted at high temperature are recovered and by means of a heat exchanger gases-water, hot water is obtained. This water can be used directly. Also, part of it can be driven to an absorption machine, in order to obtain cold water and later air conditioning for buildings.

As application of the MCFC technology a model developed in Cartagena by Navantia, type MTU HM-30, exists. This is the base of a trigeneration system, with generated powers, electrical and thermal, of $250 \mathrm{~kW}$ and $170 \mathrm{~kW}$, respectively. The reliability has reached a level of $95 \%$, and the electrical efficiency in continuous current has been about $54 \%$. After conditioning the c.c. and a.c. of $400 \mathrm{~V}$, the electrical efficiency has overcome $47 \%$. This and the use of the exhaust gases increase the global efficiency of the installation to $82 \%$.

In figure 4 , the blocks diagram that correspond with the use of fuel cell for the simultaneous production of electrical power and thermal energy can be seen.

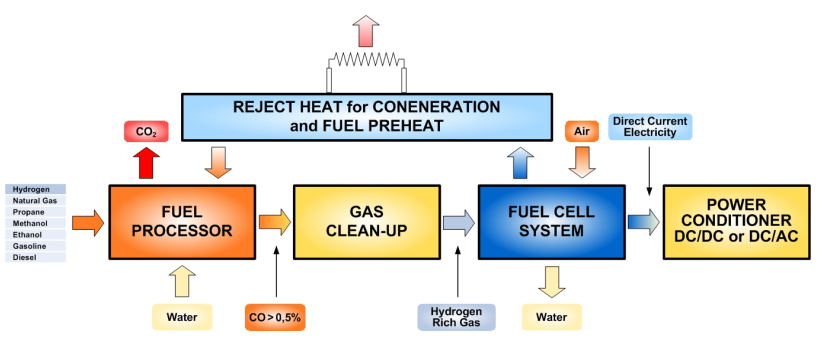

Fig. 4. Cogeneration system with fuel cell

\section{Stirling Motor}

This device is a motor of close cycle, that implies the gas is ideally inside the motor. In practice, the considered gases are hydrogen and helium, because they have a very good thermodynamic properties, [5]. This motor use an external heat source and, therefore, a lot of energy sources can be used: nuclear, fossil fuels, biomass, geothermal heat, etc. In one of the possible versions, Stirling motors can be impelled by the heat generated by parabolic mirrors that concentrate solar radiation, being this process more efficient than the use of photovoltaic cells. Also, it could be used the hot exhaust gases of automobiles, air conditioning products, natural gas that is burnt and it is not used commercially, etc.

Regenerator.- The most highlight element of a Stirling motor is the regenerator. It is a porous surface, capable of absorbing or giving heat in the evolutions if the volume is constant during the cycle, and with a worthless thermal conductivity. It divides the motor in two sides: hot and cold. Instead of a porous material, a few versions of this motor use a regenerator that consist of a matrix of metallic treads that are finely separated or metallic bands. Flow moves from the hot side to the cold one, and inverse, along the different cycles of work, crossing the regenerator. When heat is absorbed the regenerator is charged and when heat is given the regenerator is discharged. 
In the theoretical cycle, regenerator efficiency is supposed $100 \%$. So, it gives all the heat stored and besides with total recovery of temperatures. As a consequence, when the cycle is complete, regenerator is exactly in the same state that it had at the beginning. Therefore, it must be considered like a part of the motor and not like a group of external sources. For that reason, these heats will not be considered in the thermal efficiency of the cycle expression.

In figure 5, the heat, $Q_{c d}$, in the isochor evolution is given totally to the system in the also isochor evolution $a b$, being $Q_{c d}=Q_{a b}$.

The heating or cooling of the regenerator and, therefore, of the flow of work is possible whether a gradient of temperatures exists inside. When the flow get in the regenerator from the hot side it finds a porous material to $T_{c^{-}} d t$, then it gives $d Q$ to the regenerator and it is cooled in $d t$. It keeps on get in the regenerator until the flow reaches the temperature $T_{f}$. When that occurs, it does not give more heat and simply keeps on crossing the regenerator that will be charged. Discharge works in the same way, until the flow reaches the temperature $T_{c}$. If regenerator does not exist, the motor can also work but its efficiency is lower.

In the operation of the Stirling motor shown in figure 6, the following basic aspects can be highlighted:

1) The system that makes the Stirling cycle consists of a cylinder, a work piston and a displacement piston with a regenerator.

2) The external energy source is represented, in order to simplify, by a heater resistance.

3) The refrigeration circuit is represented to work with $T_{f}$. It allows extracting hot water in an cogeneration process.

4) Piston movement is synchronized in order to obtain useful work. By means of a special crankshaft, the movement of work piston and the displacement piston are out of phase $90^{\circ}$ that allows motor works.

5) It is supposed that the dead volume is cero and the gas volume inside the regenerator is worthless, in the theoretical cycle. As in the real cycle this does not occur, efficiency is a little bit lower.

6) Pistons work with a gas that is heat in an external combustion process, where the flow work (air) experiments no change of composition.

Theoretical Stirling cycle.- This cycle consists of four different reversible processes, as the Carnot cycle. Two of them are isothermics, but the adiabatics of the Carnot cycle are replaced by two processes made with the help of the regenerator.
In this type of motors, without thinking about the external processes of cogeneration that could be done, the most convenient recoverable heat source comes from the water to cool the jackets, which practically is entirely usable [5]. By other side, the motor Stirling has the possibility of working like a refrigerator, with an inverse cycle to the motor.

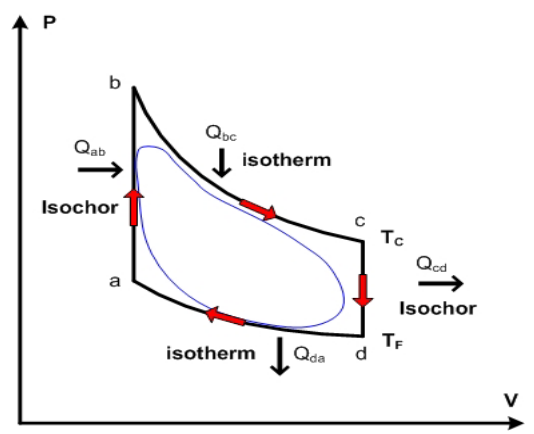

Fig.5. Real and ideal thermodynamic cycles of Stirling motor
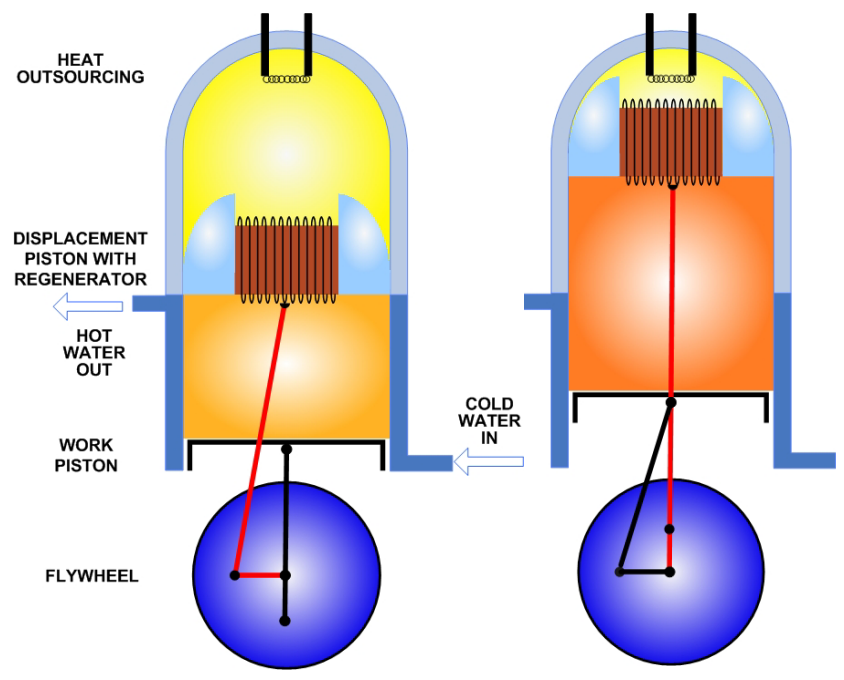

(a)
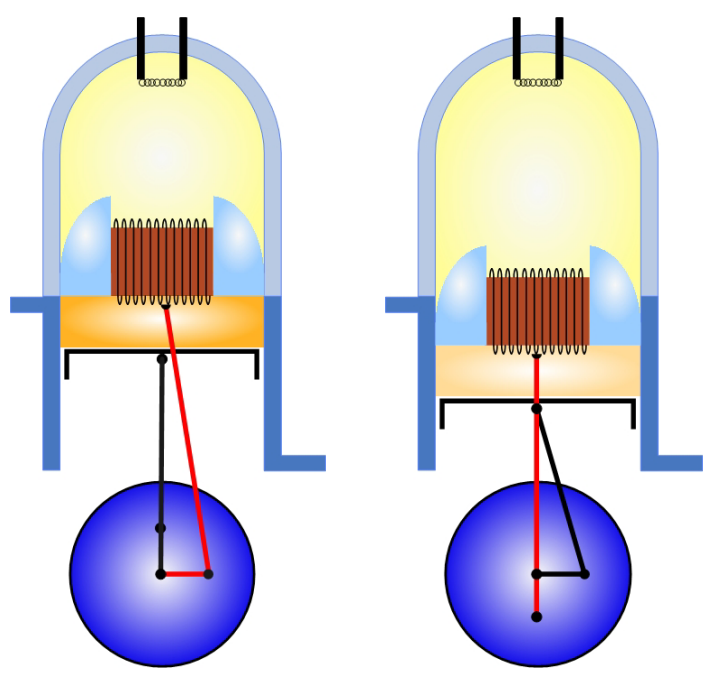

(b)

Fig. 6. Model of the Stirling motor for cogeneration 


\section{Gas microturbines}

They are an emergent technology in distributed generation. They present four different ways of working: isolated from the electrical grid, connected to the grid, dual mode with automatic transition between isolated mode and connected mode, and operating a group of them, grouped as a simple system in parallel with the grid to supply high rates of energy. Their main characteristics are: power range of 25 to $300 \mathrm{~kW}$, minimum maintenance, low noise emissions and pollutants and wide variety of fuels [6]. They are presented under two kind of modality: with simple axis or with double axis. In figure 7 , the work diagram of the simple axis microturbine is shown and in figure 8 the double axis micro-turbine model can be observed.

These micro-turbines usually contemplate multiple stages of cooling, which allows increasing notably its efficiency. Also, they allow the production of cold (trigeneration), by means of application of exhaust gases in high efficiency absorption equipments.

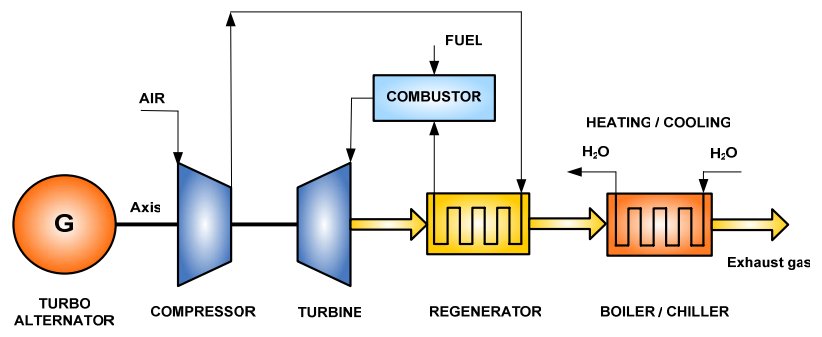

Fig. 7. Simple axis gas microturbine

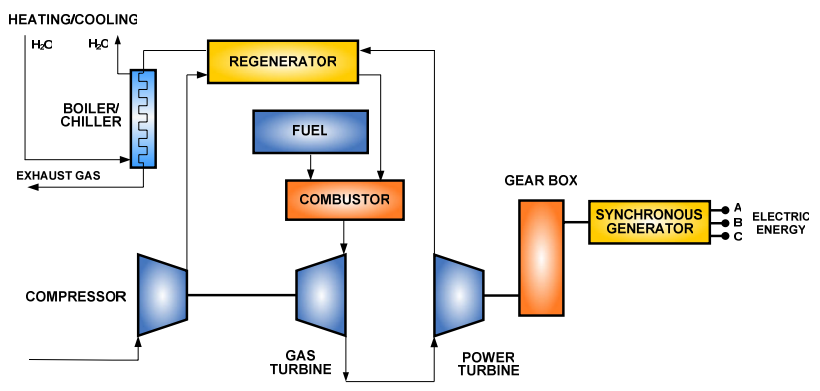

Fig. 8. Double axis gas microturbine

Finally, table 2 shows the more important properties of several microturbines that are currently operating in the market.

TABLE 2. - Microturbines characteristics [2]

\begin{tabular}{|c|c|c|c|c|c|c|}
\hline & $\begin{array}{l}\text { Electric } \\
\text { power }\end{array}$ & $\begin{array}{c}\text { Fuel } \\
\text { comsumption }\end{array}$ & $\begin{array}{l}\text { Electric } \\
\text { efficiency }\end{array}$ & $\begin{array}{l}\text { Exhaust } \\
\text { gas flow }\end{array}$ & $\begin{array}{l}\text { Thermal } \\
\text { receovered } \\
\text { power }\end{array}$ & $\begin{array}{l}\text { Nox } \\
\text { emissions }\end{array}$ \\
\hline $\begin{array}{l}\text { Capstone } \\
\text { C } 30 \text { LP }\end{array}$ & $28 \mathrm{~kW}$ & $113 \mathrm{~kW}$ & $25 \%$ & $0,31 \mathrm{~kg} / \mathrm{s}$ & $60 \mathrm{~kW}$ & $<0,22 \mathrm{~kg} / \mathrm{MWh}$ \\
\hline $\begin{array}{l}\text { Capstone } \\
\text { C } 30 \mathrm{HP}\end{array}$ & $30 \mathrm{~kW}$ & $115 \mathrm{~kW}$ & $26 \%$ & $0,31 \mathrm{~kg} / \mathrm{s}$ & $60 \mathrm{~kW}$ & $<0,22 \mathrm{~kg} / \mathrm{MWh}$ \\
\hline $\begin{array}{c}\text { Capstone } \\
\text { C } 60\end{array}$ & $60 \mathrm{~kW}$ & $214 \mathrm{~kW}$ & $28 \%$ & $0,49 \mathrm{~kg} / \mathrm{s}$ & $110 \mathrm{~kW}$ & $<0,22 \mathrm{~kg} / \mathrm{MWh}$ \\
\hline $\begin{array}{l}\text { Turbec } \\
\text { T T100 }\end{array}$ & $105 \mathrm{~kW}$ & $350 \mathrm{~kW}$ & $30 \%$ & $0,80 \mathrm{~kg} / \mathrm{s}$ & $167 \mathrm{~kW}$ & $<15 \mathrm{ppm} / \mathrm{v}$ \\
\hline $\begin{array}{l}\text { Bowman } \\
\text { TG } 80\end{array}$ & $80 \mathrm{~kW}$ & $285,1 \mathrm{~kW}$ & $27 \%$ & $0.83 \mathrm{~kg} / \mathrm{s}$ & $150 \mathrm{~kW}$ & N.A. \\
\hline
\end{tabular}

\section{Conclusion}

Cogeneration systems leave from the thermodynamic concept of thermal energy quality, which indicates that the higher thermal level, the easier the transformation in electrical o mechanical energy is. These cogeneration systems use the high temperature heat to generate electrical power in combined cycles and the low level heat to produce heat still useful for the user, not only as vapour but also as hot water.

Besides, when electrical power, heat and cold are supplied simultaneously, it is called trigeneration. For that, using a cogeneration installation, the residual heat is recovered in a partial way to start absorption equipment. A four option to generate energy is the capture, confinement and reuse of $\mathrm{CO}_{2}$ in processes to elaborate drinks and hothouses.

In the electrical micro-grids how affect these microgeneration architectures to the distribution systems and how they behave to satisfy the variable demands of electrical and thermal energy have to be analysed.

In relation with the design, aspects such as configuration, optimal conditions of operation and management of multiple systems of poligeneration have to be considered. By other side, and observing the cost of fuels and the obtained benefits, the most appropriate technologies have to be estimated.

In this paper, three emergent technologies that are capable of being used in poligeneration processes have been presented. We highlight the most relevant characteristics of the fuel cells, Stirling motor and gas micro-turbines.

\section{References}

[1] Directiva 2004/8/CE del Parlamento Europeo y del Consejo, 11 de Febrero de 2004.

[2] I. Zamora, J.I. San Martín, A.J. Mazón, J.J. San Martín, V. Aperribay, "Emergent Technologies in Electrical Microgeneration". Internacional Journal of Emerging Electric Power Systems, Volume 3, Issue 2, Article 1092, pp. 1-28, October 2005.

[3] J.M. Sala, “Cogeneración, aspectos termodinámicos, tecnológicos y económicos", Servicio Editorial, Universidad del País Vasco, 2 ${ }^{\mathrm{a}}$ Edición, 1994.

[4] "Fuel Cell Handbook", US Department of Energy, National Energy Technology Laboratory, Fifth edition, B/T books, 2000.

[5] J. Lehrfeld, "Stirling Engine Design Manual", NASA CR-135382.

[6] J.C. Bruno, L.I. Massagués, A. Coronas, "Power Quality and Air Emission Tests in a Micro Gas Turbines Cogeneration Plant", International Conference on Renewable Energy and Power Quality, España, 2003. 